\title{
Using The Jakarta Post (Daily News) To Improve Academic English Vocabulary of The United English Forum (UEF) Members In Makassar
}

\author{
Munawarah ${ }^{1}$, Ramli $^{2}$, Sudirman ${ }^{2}$ \\ ${ }^{1}$ Tribun Timur News, Makassar \\ ${ }^{2}$ Program Studi Studi Bahasa Inggris, Program Pascasarjana, Universitas Bosowa \\ E-mail: raratribuntimur@gmail.com
}

Diterima: 14Juli 2020/Disetujui 07 Desember 2020

\begin{abstract}
The objective of this research is to discover whether using The Jakarta Post newspaper could improve the academic vocabulary of UEF members in Makassar or not. The population was 100 with 40 samples. Samples were determined using random sampling technique. I used quasi experiment design where 20 members were in the control class and 20 were in the experimental class. Members of UEF Makassar in control class did not receive a treatment while those in experimental class were treated up to three meetings and given an extra article to study at home. The tests consist of 20 questions from rearranging words to translating sentences. The result shows that using English newspaper from The Jakarta Post can improve academic vocabulary of UEF members in Makassar. It can be seen from the average test scores of students before and after given treatments. The improvement was quite significant from 47.75 to 81 . It was proven by the result of the statistical analysis of the significant level, $p=5 \%$ dan $p=1 \%$, with degree of freedom $(d f)=38$ indicating that the $t$-test value of the students' academic vocabulary (3,246) was higher than t-table value $(2,02$ and 2,71) or 2,02 <3,246> 2,71.
\end{abstract}

Keywords: Academic English Vocabulary, The Jakarta Post

\section{Introduction}

All words in English language or vocabulary are the fundamental to succeed language acquisition. It is the core of reading, writing, listening and speaking skills. Wilkins (2002) emphasizes that nothing can be delivered without vocabulary and very little can be conveyed without vocabulary. Academic vocabulary is essential for university students. They will read academic textbooks, write an essay, answer exam questions and explain their homework or deliver an idea using academic vocabularies while speaking. Common vocabularies are used in casual communication and academic vocabularies are used in academic environment. Academic vocabularies are used for classroom communication, formal forum, writing journals and others writing for professional including in seminar preparing for TOEFL and IELTS. For instance, the vocabulary 'kidnap' is usually used in general writing but in TOEFL or academic writing we use 'abduct' and it is the academic vocabulary of kidnap. Further explanation is in Oxford Advanced Learner's Dictionary, International Students' Edition, Oxford Writing Tutor.

Academic vocabulary is essential for university students. They will read academic textbooks, write an essay, answer exam questions and explain their homework or deliver an idea using academic vocabularies while speaking. Common vocabularies are used in casual communication and academic vocabularies are used in academic environment. Academic vocabularies are used for classroom communication, formal forum, writing journals and others writing for professional including in seminar preparing for TOEFL and IELTS. For instance, the vocabulary 'kidnap' is usually used in general writing but in TOEFL or academic writing we use 'abduct' and it is the academic vocabulary of kidnap. Further explanation is in Oxford Advanced Learner's Dictionary, International Students' Edition, Oxford Writing Tutor.

Schmitt (2011) argued that learning vocabulary or studying words from academic text will increase students' academic vocabularies and their academic styles. At least there are three reasons why learning vocabulary is necessary for language learning and reading. They are to know the meaning of words which will improve comprehension and there will be no without words communication. Alexander (2011) stated that poor vocabulary is an obstacle to write, to read, to listen and to speak. Finally, improving vocabulary can make students confident to socialize and their competence will improve.

Seminars, lectures, articles and academic textbooks also use academic vocabularies. An IELTS test also requires academic vocabulary competence and everything related to college. O’Dell (2008) believes that application form, money, education and academic course associated with university life need academic vocabulary comprehension.

English comprehension improves when students learn more words and expressions because vocabulary is the key of communication. Thorburry (2020) said that without vocabulary nothing can be delivered and with grammar very little can be conveyed. There are a lot of ways to improve academic English vocabulary. One of them is reading The Jakarta Post daily news. The Jakarta Post is printed and online news that we can have in Indonesia such as in Makassar.

The language that is used is English and it is written and edited by journalists who have a high score in TOEFL and IELTS. Therefore, they will use academic vocabularies. Reading The Jakarta Post can improve our writing in English and make students easy to learn the list of academic vocabulary as well as they can choose what topic that they would like to choose as The Jakarta post has many topics.

Benson (2000) believes that students respond positively when the teachers allow students to set their goals and permit to self-manage their work so the students will accomplish their work. The students are also responsible and highly motivated. 
The Jakarta Post daily news is one of the authentic materials that can be used in classrooms for teaching. Using authentic material in class is not a new thing as Kilickaya (2004) defines authentic material is an exposure to real language and use in its own community.

I investigated members of United English Forum (UEF) Makassar. It is an English community in which the members are from different universities. However, this research was focused on UIN Alauddin State Islamic students. I did not choose the early semester because I needed students who had a basic in English particulary in vocabulary. Before doing a survey, I observed the student whether they had learnt vocabulary or academic vocabulary before or not. I found that the students only learned the basic of vocabulary. With the result, the students needed to learn more detailed academic vocabularies.

I had done survey in United English Forum (UEF) Makassar members and took of paragraphs in Jakarta Post daily news as follows.

"President Joko 'Jokowi' Widodo is making three days visit to Papua and West Papua the first trip of his second term, and the first sojourn to the country's easternmost provinces since unrest broke out in the region in August"

The paragraph above was published in Jakarta Post Newspaper daily news under the title Development Kept as Top Priority in Papua Policy at Monday October 2019. A paragraph reported that Jokowi visited Papua and West Papua in three days at his second period as the president of Indonesia. Jokowi enjoyed a sojourn in the easternmost provinces since unrest occurred in the region at August.

The text above is one of the paragraphs in The Jakarta Post newspaper that were used by the reseacher to test the students' academic English vocabulary. I did survey to 10 students. The reseacher gave the text and asked students to translate it and marked vocabularies that they did not know. The result of the survey indicated that the students were not familiar with academic vocabularies such as sojourn and unrest. Based on the survey results, I concluded that the students did not understand and that is the problem should be solved.

I believe that using The Jakarta Post newspaper may help students fix the lack of academic vocabulary acquisition. I chose The Jakarta Post as it is the most famous daily English newspaper published in Indonesia. Simpson (2003) suggests some advantages of reading newspaper articles. Besides obtaining up to date news and advertising, students also will enrich their academic vocabulary by reading some articles as the authentic material. Newspaper instils the students reading habit with its interesting news.

\section{Research Method}

This research is a quasi-experiment which is an experiment with two classes named control and experiment. All the samples do not meet all the requirements necessary for controlling the influence of extraneous variables (Larry et al, 2007). The control class contrasted with experiment class in the process of collecting data. All the samples in experiment class were treated in three meeting. Henceforth the final score of the pre-test and post-test both control and experiment class were compared before taking a conclusion of this research. The sample of this research was divided into two classes or groups. Those were in control and experiment groups. Students in the experiment group were given a treatment but not for those in the control group.

Random sampling technique was applied in this research. Sugiyono (2001) explained simple random sampling technique is picking a sample from population not based on strata randomly. I choose two groups to represent the experimental cluster for UEF group 2 and control cluster for UEF group 1. The total number of the samples were 40 students that consisted of 20 students for the experimental group and 20 students for the control group.

The research instrument was a test. I collected the data by using a test to measure achievement, performance, aptitude and personality (Larry, Burke \& Lisa, 2007). I gave 20 items test. All four tests had a test name. The first was rearrange letter. I gave five questions consisting of definition of words. Then the definition would help the students to guess and arrange the letter to be a word. The second type of test was sentence completion. I gave five questions then the students were asked to fill a word in the blank sentences. The third was that students were asked to find the synonym of five words. Finally, the last test was translation. I gave five texts in Indonesian language then the students were asked to translate them into English.

\section{Result dan Discussion}

The following table of frequency shows the students' scores in the pre-test and post-test of the control class. Nine students gained score between 20-24 in the pre-test and five members in the post-test. Seven students scored in the range 2539 in the pre-test and three students in the post-test. Forty to fifty-four scores are achieved by three students in the pre-test and eight students in the post-test. Then only one student in the pre-test and four students in the post-test got 55 to 69.

Table 1. The Rate Frequency of the Pre-Test and Post-Test in Control Cluster

\begin{tabular}{c|c|c|c}
\hline Number & Score & Frequency of The Pre-Test & Frequency of The Post-test \\
\hline 1 & $70-74$ & 0 & 0 \\
2 & $55-69$ & 1 & 4 \\
3 & $40-54$ & 3 & 8 \\
4 & $25-39$ & 7 & 3 \\
5 & $10-24$ & 9 & 5 \\
\hline & $\mathbf{N}$ & 20 & 20 \\
\hline
\end{tabular}


The table below shows the students' scores in the pre-test and post-test of the experiment group. Eight students achieved score between 10-39 in the pre-test and none of members in the post-test. Eleven students scored in the range 40 to 69 in the pre-test and none of students in the post-test and only one student reached 70-99 score in the pre-test and 20 students in the post-test.

Table 2. The Rate Frequency of the Pre-Test and Post-Test in Control Cluster

\begin{tabular}{c|c|c|c}
\hline Number & Score & Frequency of The Pre-Test & Frequency of The Post-test \\
\hline 1 & $100-129$ & - & - \\
2 & $70-99$ & 1 & 20 \\
3 & $40-69$ & 11 & 0 \\
4 & $10-39$ & 8 & 0 \\
\hline & $\mathrm{N}$ & 20 & 20 \\
\hline
\end{tabular}

Table 3. The Mean Score and the Standard Deviation

\begin{tabular}{|c|c|c|c|c|}
\hline \multirow{2}{*}{ Group } & \multicolumn{2}{|c|}{ Mean Score } & \multicolumn{2}{|c|}{ Standard Deviation } \\
\hline & Pre-test & Post-test & Pre-test & Post-test \\
\hline $\begin{array}{l}\text { Experiment } \\
\text { Control }\end{array}$ & $\begin{array}{l}39.75 \\
24.75\end{array}$ & $\begin{array}{l}83.50 \\
39.75\end{array}$ & $\begin{array}{l}15.259 \\
15.085\end{array}$ & $\begin{array}{c}8.599 \\
15.259\end{array}$ \\
\hline
\end{tabular}

The table above illustrated the mean point before the treatment in the experiment cluster was 39.75 with standard deviation 15.259 and mean point after the treatment was given 83.50 with standard deviation 8.599 . The mean point before giving the treatment in the control cluster was 24,75 with standard deviation 15.085 and mean point after the treatment was 39.75 with standard deviation 15.259 .

This research demonstrated that using The Jakarta Post has improved UEF Makassar members' academic vocabulary. It is shown by the lowest and the highest point before and after the treatment in which twenty (20) as the lowest point before the treatment was given while seventy (70) was the lowest point after the treatment was given for the experimental class. In addition, seventy (70) was the highest point before giving the treatment and ninety-five (95) is the highest point after the treatment.

The improvement was proven by the lowest and the highest point after giving the treatment. Fifteen (15) was the poor point after giving the treatment of control class while seventy (70) was the lowest point after the treatment was given to the experiment class. Besides, sixty-five (65) was the highest point in the post-test of control class and ninety-five (95) was the highest point after giving the treatment in experiment class.

This study revealed the average scores of UEF members in pre-test of experiment class which was 39.75 increased to 83.50 in the post-test or after giving the treatment. Repeated activities were the key to success of improvement. Repetition helped students to be more confident in practicing their language. It assisted students to interpret what is going on (Harmer, 1998).

Compared to previous research, Ahmed (2016) found that reading an English newspaper helped students to learn new English words but he did not find a detail data showed students' vocabulary improved. Likewise, Rohmatilla (2016) revealed students' academic vocabulary improved through reading The Jakarta Post.

Previous studies strengthened the findings that using English newspaper improved students' vocabulary. Grundy (1993) states that language teacher tend to use newspaper to evolve language competences including grammar, vocabulary and reading. By reading a text, language learner has a possibility to master language vocabulary, grammar, punctuation and the way construct sentences, paragraphs and texts (Thornburry, 2001). In addition, students will encounter most new academic vocabularies when they read and they will also need to be able to use these words when they speak, listen and write (Schmitt, 2011).

The similarity of the previous studies and this research was all of them used The Jakarta Post. The difference was the substance of research where the previous studies focused on improving senior high school students' vocabulary while this research focuses on enhancing university students' academic vocabulary and I gave an additional treatment to UEF members by giving extra articles to read at home.

\section{Conclusions}

In conclusion, using The Jakarta Post can improve academic vocabulary of the members of UEF Makassar. The findings explain that there was an improvement of academic vocabulary acquisition. It is shown by the increase in scores of students in pre-test of experimental class from 39.77 to 83.50 after the treatment in three meetings. Members of UEF Makassar was treated by giving them the article of The Jakarta Post and they read more articles at home.

Another supporting indicator was t-test value which was higher than $t$-table value $0.433<1.232$ and $0.549<1.232$. It indicated that there was a significant difference between pre-test and post-test in experimental group. Therefore, it means that using newspaper of The Jakarta Post improved academic vocabulary of the members of UEF Makassar. In conclusion, English newspaper of The Jakarta Post is an effective media to use in learning and teaching academic vocabulary in an English meeting club. Explanations and data collected show that using the article of the Jakarta Post is effective to improve UEF Makassar members' academic English vocabulary. 


\section{References}

Ahmed, Raju. (2016). The Study Focuses on The Effectiveness of English Newspapers in Improving Vocabulary and Reading Skills. Dhaka of University.

Alexander, Francia. (2011) Understanding Vocabulary. 2011. London and New York: Longman Group.

Best, W. John. (1981). Research in Education. Fourth Edition. New Jersey: Prentice Hall, Inc, Englewood.

Benson, M.J. (1991). Attitudes and motivation towards English: A survey of Japanese freshmen. RELC Journal, 22(1), 34-48.

Christensen, Johnson \& Turner., (2014). Research Methods, Design, and Analysis. Pearson.

Cohen, Louis, Lawrence Manion, Keith Morrison. (2007) Research Methods in Education (sixth edition). New York: Routledge.

Dhiny. (2018). The Effectiveness of Using Jakarta Post to Improve Students' Reading Comprehension at The Tenth Grade of The Second Semester of SMAN 01 Abung Semuli North Lampung. Lampung

Kilickaya, F. (2004) Authentic materials and culture content in EFL classrooms. The Internet ELT Journal, 10(7).

Gay, L.R. (2016) Educational Research. Warehouse, United States.

Grundy, Peter. (1993). Newspaper. Oxford University Press.

Harmer, Jeremy. (1991) The Practice of English Language Teaching. London and New York: Longman Group.

Horby. A.S. (1995). Oxford Advanced Learners Dictionary of Current English. Britain: Oxford University Press. 